\title{
Dual Inoculation with Mycorrhizal and Saprotrophic Fungi Applicable in Sustainable Cultivation Improves the Yield and Nutritive Value of Onion
}

\author{
Jana Albrechtova, ${ }^{1,2}$ Ales Latr, ${ }^{3}$ Ludovit Nedorost, ${ }^{4}$ \\ Robert Pokluda, ${ }^{4}$ Katalin Posta, ${ }^{5}$ and Miroslav Vosatka ${ }^{2,3}$ \\ ${ }^{1}$ Department of Experimental Plant Biology, Faculty of Science, Charles University in Prague, 12844 Vinicna 5, Czech Republic \\ ${ }^{2}$ Institute of Botany of the Academy of Sciences of the Czech Republic, 25243 Pruhonice, Czech Republic \\ ${ }^{3}$ Symbiom Ltd., Sazava 170, 56301 Lanskroun, Czech Republic \\ ${ }^{4}$ Department of Vegetable Sciences and Floriculture, Mendel University in Brno, Valticka 337, 69144 Lednice, Czech Republic \\ ${ }^{5}$ Microbiology and Environmental Toxicology Group, Plant Protection Institute, Szent István University, 2100 Gödöllo, Hungary
}

Correspondence should be addressed to Jana Albrechtova, albrecht@natur.cuni.cz

Received 19 October 2011; Accepted 25 December 2011

Academic Editors: O. K. Douro Kpindou, A. Ferrante, R. L. Jarret, and A. Roldán Garrigós

Copyright ( 2012 Jana Albrechtova et al. This is an open access article distributed under the Creative Commons Attribution License, which permits unrestricted use, distribution, and reproduction in any medium, provided the original work is properly cited.

\begin{abstract}
The aim of this paper was to test the use of dual microbial inoculation with mycorrhizal and saprotrophic fungi in onion cultivation to enhance yield while maintaining or improving the nutritional quality of onion bulbs. Treatments were two-factorial: (1) arbuscular mycorrhizal fungi (AMF): the mix corresponding to fungal part of commercial product Symbivit (Glomus etunicatum, G. microaggregatum, G. intraradices, G. claroideum, G. mosseae, and G. geosporum) (M1) or the single-fungus inoculum of G. intraradices BEG140 (M2) and (2) bark chips preinoculated with saprotrophic fungi (mix of Gymnopilus sp., Agrocybe praecox, and Marasmius androsaceus) (S). The growth response of onion was the highest for the M1 mix treatment, reaching nearly $100 \%$ increase in bulb fresh weight. The effectiveness of dual inoculation was proved by more than $50 \%$ increase. We observed a strong correlation $(r=0.83)$ between the growth response of onion bulbs and AM colonization. All inoculation treatments but the single-fungus one enhanced significantly the total antioxidant capacity of bulb biomass, was the highest values being found for $\mathrm{M} 1, \mathrm{~S}+\mathrm{M} 1$, and S + M2. We observed some induced enhancement of the contents of mineral elements in bulb tissue (Mg and $\mathrm{K}$ contents for the M2 and M2, S, and S + M2 treatments, resp.).
\end{abstract}

\section{Introduction}

Soil organisms play a crucial role in the functioning of soil agricultural ecosystems. The functions performed by the soil biota have major direct and indirect effects on soil quality, crop growth and quality, its disease resistance, and thus on the sustainability of crop production systems [1]. Sustainable agriculture centres its focus on developing new comprehensive farming practices including management of soil microorganisms that are safe and environmentally friendly fostering the development of multidisciplinary studies [2].
Among soil microorganisms, arbuscular mycorrhizal fungi (AMF) are regarded as essential components of sustainable soil-plant systems. Since the "first green revolution," which saw the intensification of agriculture relying on highdosage fertilization, however, less attention has been given to beneficial soil microorganisms in general and to AM fungi in particular [3, 4]. Mycorrhiza has numerous benefits for sustainable crop production. It can function as an ecological biofertilizer, a biocontrol agent against soil-borne pathogens, a bioprotectant against toxic stresses, or a soil-improver acting as a soil antierosion factor [5, 6]. Moreover, new functions of mycorrhiza in crop production are currently 
being explored. For example, it has been reported that AM fungi are useful for phytoremediation of contaminated soils, for example, by organophosphorus pesticides, concentration of which is high worldwide [7]. AM fungi show promising potential for reducing organophosphorus pesticide residues in plant tissues as it was shown in recent study on green onion [7].

Native AMF populations are often reduced by soil management practices of conventional agriculture such as tillage, high-dosage use of systemic fungicides, and soluble phosphate fertilizers. These practices select against conditions favourable for the survival and development of AMF. The AMF biodiversity is often reduced in high-input systems compared to low-input ones $[8,9]$.

Synergistic inoculations bring benefits to plant production, so they are already sought after. This, for example, applies to dual inoculations consisting of AMF and rhizobacteria, which promote plant-growth together [10]. Dual inoculations involving saprotrophic fungi can exhibit a beneficial effect on the growth of mycorrhizal plants. Members of the saprobic genus Trichoderma have emerged as an especially promising group of microbial inoculants when Trichoderma genotypes supporting plant growth were found $[11,12]$.

Onion production in high-input cropping systems relies on high dosage of fertilizers to achieve high yields [13] since the yields are higher by almost 50\% compared to organic systems, as has been documented in the Netherlands [14]. Phosphorus availability, which often determines the plant root mycorrhizal colonization and response to mycorrhiza, is usually lower in organic systems compared to conventional ones. This has been confirmed in an extensive study of onion fields in which the average phosphorus concentration $\left(P_{w}\right)$ in organic soils was up to $27 \%$ lower than in conventional soils [14]. A pioneering study on the performance of mycorrhizal onion under field conditions has shown that smaller growth benefits from mycorrhiza are observed under high phosphorus-levels than in phosphorusdeficient soils [15]. New strategies are, therefore, sought to improve phosphorus uptake and use by onion plants. Researchers focus, for example, on breeding towards improving the root system and its architecture and enhancing the responsiveness to mycorrhiza, which aids water and nutrient uptake in plants [14].

Onion contains high amounts of a variety of antioxidants, mainly of flavonoid character (quercetin, luteolin, kaempferol, etc.), of which quercetin glycosides represent the highest portion [16]. Onion is, therefore, considered a fundamental vegetable that has been valued for its medicinal qualities since ancient times. Modern research has revealed that onion possesses antibiotic, anticarcinogenic, anti-inflammatory, and antioxidative properties [17]. Biotests suggest that a diet including onion may be beneficial for the elderly as a means of improving antioxidant status [18]. Onion extracts have been reported to be effective in treating cardiovascular diseases thanks to their hypocholesterolemic, hypolipidemic, antihypertensive, antidiabetic, antithrombotic, and antihyperhomocysteinemia effects [19].

Recent studies document that mycorrhiza can enhance the nutritive value of crop plants, for example, increase the content of antioxidants in artichoke [20]. Leaf antioxidant content can also be increased by adding an organic fertilizer instead of a conventional nitrogen source, which simultaneously promotes soil biota activity and mycorrhizal colonization, as shown for highbush blueberries [21].

The aim of the present study was to evaluate a possible sustainable, ecological way of producing onion using synergistic microbial treatments with mycorrhizal and saprotrophic fungi while increasing yield and maintaining or improving the nutritional quality of onion bulbs.

\section{Materials and Methods}

2.1. Experiment Site, Plant, and Substrate Materials. Pot experiment was located outdoors in field conditions at the Horticultural Faculty in Lednice (Location: $48^{\circ} 47^{\prime} 54.502^{\prime \prime} \mathrm{N}$; $16^{\circ} 48^{\prime} 0.39^{\prime \prime} \mathrm{E}$, Czech Republic) in 2009. Seeds of Allium cepa L. (Alliaceae) cv. "ALICE" (SEMO a.s.) were sown on 24th February, and seedlings were planted into experimental 10 litre pots on 23rd April. For both the sowing and the pot experiment, we used a sterile substrate mixture composed of zeolite: peat:bark chips: bentonite $(3: 3: 2: 1 ; \mathrm{v} / \mathrm{v} / \mathrm{v} / \mathrm{v})$. Substrate sterilization was done by gamma radiation (min. $25 \mathrm{kGy}$, company Artim s.r.o., Prague, CZ, http://www.artim.cz/). Basic chemical and physical properties of the substrate were $75.76 \%$ of dry matter, $14647 \mathrm{mg} \cdot \mathrm{kg}^{-1}$ of $\mathrm{K}, 533 \mathrm{mg} \cdot \mathrm{kg}^{-1}$ of $\mathrm{P}, 1159 \mathrm{mg} \cdot \mathrm{kg}^{-1}$ of $\mathrm{N}$, $0.015 \mathrm{mg} \cdot \mathrm{kg}^{-1}$ of S, $1250 \mathrm{mg} \cdot \mathrm{kg}^{-1}$ of $\mathrm{Mg}, 2536 \mathrm{mg} \cdot \mathrm{kg}^{-1}$ of $\mathrm{Ca}$, and $\mathrm{pH}$ 4.47. Before seedlings were planted, the substrate was fertilized, based on a chemical analysis, with $660 \mathrm{mg}$ of $\mathrm{P}_{2} \mathrm{O}_{5}$ and amended with $5.4 \mathrm{~g}$ of $\mathrm{CaCO}_{3}$ per pot to achieve $\mathrm{pH}=6.4$. The electric conductance of the substrate was $0.18 \mathrm{mS} \cdot \mathrm{m}^{-1}$.

\subsection{Experimental Design with Microbial Treatments. Micro-} bial treatments consisted of combination of two factors: (1) an AM fungal treatment (AMF)-either a mixed Glomus sp. inoculum (M1) or a single-isolate (M2); (2) bark chips preinoculated with saprotrophic fungi (S). The treatment M1 was a mixture of AM fungi corresponding to the composition of a fungal part of a commercial product Symbivit (Symbiom s.r.o., http://www.symbiom.cz/): Glomus intraradices BEG140, G. mosseae BEG95, G. etunicatum BEG92, G. claroideum BEG96, G. microaggregatum BEG56, and G. geosporum BEG199, only without the bioadditives that are used in the standard commercial product. The treatment M2 was a single-fungus inoculum of $G$. intraradices BEG140. The treatment $S$ represented bark chips preinoculated with saprotrophic fungi. Saprotrophic fungi effective in wood decomposition (Gymnopilus sp. isolate IZO24, Agrocybe praecox isolate AER1, and Marasmius androsaceus isolate MAN1) were inoculated on nonsterile pine bark chips (chip size 7-15 mm, TerraSan, http://www.terrasan.de/online/index.php) in a mixture $(1: 3.3, \mathrm{v} / \mathrm{v})$ and were left to grow for 3 months at $25^{\circ} \mathrm{C}$. The AER- 1 strain was derived from a fruit body in 2005 and identified based on morphological characteristics and ITS rDNA sequence similarity to AM905094 (derived from an A. praecox sporocarp) and AY194531 (derived from an 
A. praecox sporocarp, voucher MSC 378486). The final treatments tested were Ctrl (control, nontreated plants), M1, M2, $\mathrm{S}$ and $\mathrm{S}+\mathrm{M} 1, \mathrm{~S}+\mathrm{M} 2$ combinations of two mycorrhizal inoculants with saprotrophic amendment. Each of 6 treatments involved 7 pot replicates, each pot contained 3 seedlings.

Fungal inocula were supplied by the company Symbiom s.r.o. The mycorrhizal inoculum (M1 or M2) was added as a mixture of the cultivation substrate, colonized roots, and mycelium fragments (grown as single AMF cultures on maize as the host plant for 5 months in zeolite) in a dose of $120 \mathrm{~g}$ into each planting hole approx. $3 \mathrm{~cm}$ below each seedling. Bark chips preinoculated with saprotrophic-fungi (S) were added to the bottom of cultivation pots in the amount of $500 \mathrm{~mL}$ mixed with $2.5 \mathrm{~L}$ of cultivation substrate per $10 \mathrm{~L}$ pot (in $S$ treatments thus replacing part of the cultivation substrate by uninoculated bark chips). Plants were regularly fertilized with the leaf fertilizer Wuxal super (containing $98 \mathrm{~g} / \mathrm{L} \mathrm{N}, 98 \mathrm{~g} / \mathrm{L} \mathrm{P}_{2} \mathrm{O}_{5}, 73 \mathrm{~g} / \mathrm{L} \mathrm{K}_{2} \mathrm{O}$ and trace elements B, Fe, $\mathrm{Cu}, \mathrm{Mn}, \mathrm{Mo}, \mathrm{Zn}$ in physiological concentrations; product of AgroBio s.r.o. Opava, CZ, http://www.agrobio.cz/intro/) starting 8 weeks after planting (the fertilization dates: 08/06, 20/06, 02/07, 13/07, 22/07, 19/08).

2.3. Harvests, Plant Analyses, Mycorrhizal Parameters. The plants were harvested, measured, and sampled for plant analyses after 4 months of cultivation at 21st August 2009. The dry mass values of bulbs, shoots, and roots were recorded after drying to constant weight at $105^{\circ} \mathrm{C}$ in a drying oven Sterimat 574.2 (BMT, Czech Republic) for at least $24 \mathrm{~h}$. Roots of all plants were sampled to determine AM colonization. All onion bulbs were sampled for analysis of antioxidant capacity and contents of mineral elements (a $10 \mathrm{~g}$ sample for each), and mixed $10 \mathrm{~g}$-samples per treatment were prepared for the vitamin $\mathrm{C}$ content analysis.

2.4. Antioxidant Capacity Determination FRAP Assay. Onion bulb samples $(10 \mathrm{~g})$ were homogenized in a blender with $30 \mathrm{~mL}$ ethyl alcohol (50\% concentration), homogenate was added with ethyl alcohol (50\% concentration) to amount of $50 \mathrm{~mL}$, filtered, centrifuged ( $3800 \mathrm{rt} / \mathrm{min}$ for 10 minutes), and the supernatant was used for the measurement. Total antioxidant capacity (TAC) was determined using the ferricreducing antioxidant power (FRAP) assay developed by Benzie and Strain [22]. In the FRAP assay, reductants ("antioxidants") present in the extract reduce $\mathrm{Fe}(\mathrm{III})$-tripyridyltriazine (TPTZ) complex to its intensely blue ferrous form with an absorption maximum at $593 \mathrm{~nm}$. The working FRAP reagent was prepared fresh on the day of the analysis by mixing acetate buffer, $10 \mathrm{mM}$ TPTZ solution, and $20 \mathrm{mM}$ ferric chloride solutions in the ratio of $10: 1: 1(\mathrm{v} / \mathrm{v} / \mathrm{v})$. The mixture was incubated at $37^{\circ} \mathrm{C}$. The absorbance was monitored for $4 \mathrm{~min}$ in a temperature-controlled cuvette held at $37^{\circ} \mathrm{C}$ using a JENWAY 6100 spectrophotometer (AIR, UK).

The final total antioxidant capacity was expressed in mg equivalent of Trolox in $100 \mathrm{~g}$ of fresh biomass ( $\mathrm{mg}$ Trolox $\left.\cdot 100 \mathrm{~g}^{-1}\right)$. For quantification, a calibration curve of Trolox was prepared with dilutions from $50 \mathrm{mg} / \mathrm{L}$ to $700 \mathrm{mg} / \mathrm{L}$.
2.5. Contents of Mineral Elements. Contents of $\mathrm{Na}, \mathrm{K}, \mathrm{Ca}$, and $\mathrm{Mg}$ were determined by the method of capillary isotachophoresis using the IONOSEP 2003 device (RECMAN, CZ) following method described by Blatny et al. [23]. Onion bulb samples $(10 \mathrm{~g})$ were homogenized and diluted with distilled water $(1: 40)$ and then analysed. The head of

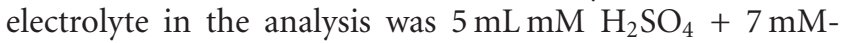
18-crown-6 $+0.1 \%$ HPMC $^{1}$ (hydroxypropyl methylcellulose). The terminating electrolyte was $10 \mathrm{mM} \mathrm{BTP}^{1}$ (bis-tris propane). The drive current was $100 \mu \mathrm{A}$ at the beginning and $50 \mu \mathrm{A}$ at the end. The amount of each mineral element was expressed as $\mathrm{mg}$ per $\mathrm{kg}$ of onion bulb fresh weight.

2.6. Vitamin C-Ascorbic Acid (AA) Content. The concentration of vitamin $\mathrm{C}$ (ascorbic acid) was determined only in compound $10 \mathrm{~g}$ samples combined from bulbs harvested in each treatment by HPLC according to Arya et al. [24] with slight modification. Onion bulb samples were homogenized in a blender with $75 \mathrm{~mL}$ of $0.1 \mathrm{M}$ oxalic acid. The homogenate was topped up with oxalic acid to the volume of $100 \mathrm{~mL}$, filtered, and centrifuged $(3800 \mathrm{rt} / \mathrm{min}$ for 10 minutes), and the supernatant was used for measurement. The analyses were performed by RP-HPLC in a LCO-101 column placed in an Ecom thermostat $\left(t=30^{\circ} \mathrm{C}\right)$, mobile phase TBAH (tetrabutylamonium hydroxide) :0.1 M oxalic acid: water in the ratio of $10: 20: 70(\mathrm{v} / \mathrm{v} / \mathrm{v})$, flow $0.5 \mathrm{~mL} / \mathrm{min}$ at $254 \mathrm{~nm}$ using a UV-VIS detector. The amount of AA was expressed as $\mathrm{mg} \cdot 100 \mathrm{~g}^{-1}$ of fresh weight.

2.7. Mycorrhizal Colonization. Mycorrhizal root colonization was evaluated in root samples taken from root systems of experimental plants (3 samples corresponding to 3 plants per pot). Samples were stained with $0.05 \%$ trypan blue in lactoglycerol [25] and quantified by the modified grid-line intersect method [26] using an ocular grid at a 100x magnification.

2.8. Statistical Analysis. We analysed the results of our experiments using Statistica 9.0 software (StafSoft Inc. 19842009). We tested the data for normal distribution and homogeneity of variance by Bartlett's test. The effects of experimental factors were evaluated by the analysis of variance (ANOVA), and comparisons between means were carried out using Tukey HSD test at the significance level of $P<0.05$. Data on root colonization were arcsine/logarithmically transformed in order to meet the requirements of ANOVA prior to the statistical analysis. Measure of variability of a mean value throughout the text is expressed by \pm SD. Linear correlation was evaluated with Pearson coefficient $r, P<$ 0.05 .

\section{Results}

Onion growth measured as the bulb fresh biomass was significantly enhanced by three experimental inoculation treatments (Figure 1(a)).

Bulb fresh weight was the highest for the M1 mix treatment, reaching nearly a $100 \%$ increase in bulb fresh biomass comparing to control. The effectiveness of dual inoculation 


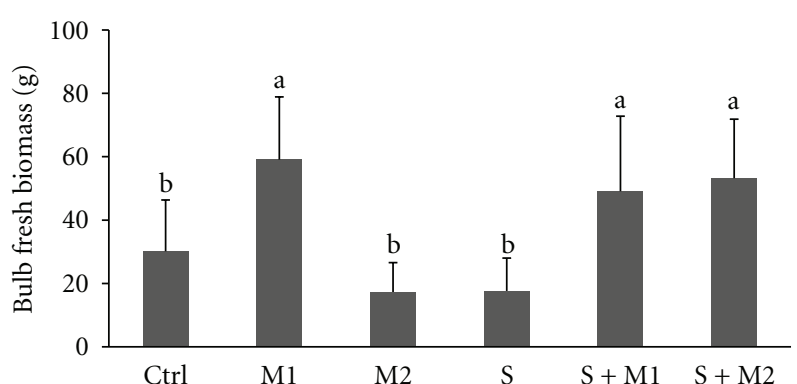

(a)

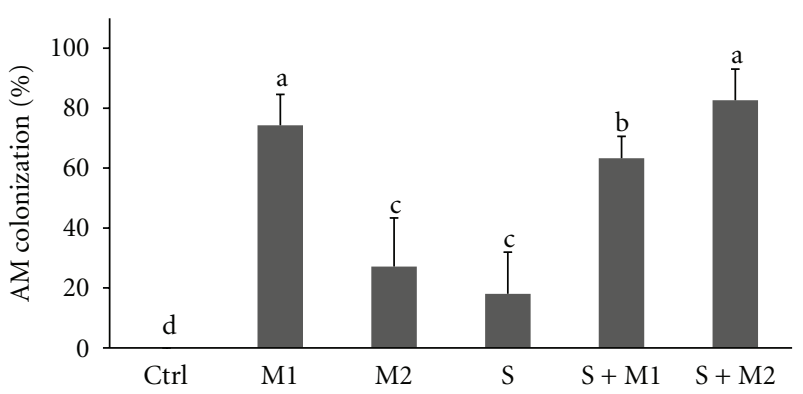

(b)

Figure 1: Response of onion to inoculations: (a) bulb fresh biomass, (b) AM colonization. Treatments: Ctrl—Control, M1—the mix of Glomus sp. (G. intraradices BEG140, G. mosseae BEG95, G. etunicatum BEG92, G. claroideum BEG96, G. microaggregatum BEG56, G. geosporum BEG199), M2-G. intraradices BEG140, S-saprophytic fungi preinoculated bark chips (Gymnopilus sp. IZO24, Agrocybe praecox AER1, Marasmius androsaceus MAN1), S + M1, S + M2. Means \pm SD, columns marked with the same letters are not significantly different at the level $P<0.05$, Tukey HSD Test, $n=19$.

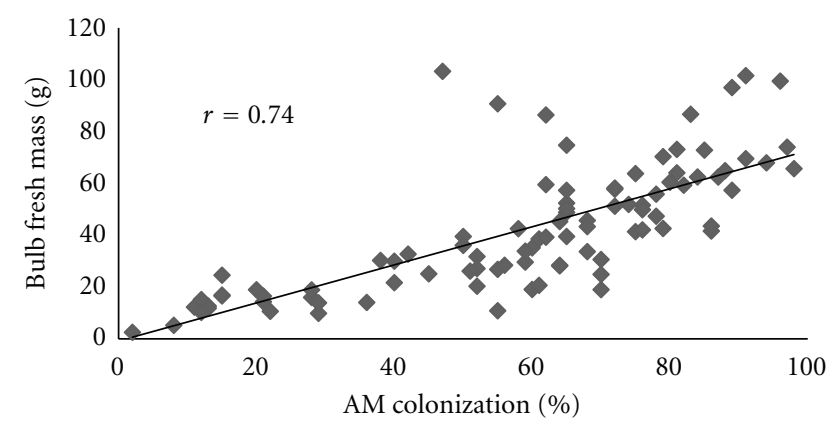

Figure 2: Relationship between root AM colonization (\%) and bulb fresh weight $(\mathrm{g})$ for all plants in inoculated treatments (M1, M2, $\mathrm{S}, \mathrm{S}+\mathrm{M} 1, \mathrm{~S}+\mathrm{M} 2$ ) expressed as linear correlation, $r$-Pearson correlation coefficient, $P<0.05, n=92$.

in both treatments $(\mathrm{S}+\mathrm{M} 1, \mathrm{~S}+\mathrm{M} 2)$ was proved by a more than $50 \%$ significant increase comparing to control. The lowest bulb yield was in the control and in the treatment inoculated with the saprotrophic fungus or the G. intraradices $\mathrm{M} 2$ inoculum.

Roots of onion plants of all inoculated treatments were colonized with the exception of the control, noninoculated onion plants (Ctrl). As expected, the highest rate of colonization was found for the treatments that involved mycorrhizal inoculation $(\mathrm{M} 174.3 \pm 10 \%$, M2 $27.2 \pm 16.2 \%, \mathrm{~S}+\mathrm{M} 1$ $63.3 \pm 7.3 \% \mathrm{~S}+\mathrm{M} 282.6 \pm 10.4 \%$ ) (Figure 1(b)). The observed AM colonization of plants inoculated with saprobes only (S) was rather unexpected, but AM colonization caused by airborne mycorrhizal propagules could not been fully prevented since the experiment was kept outdoor. Mycorrhizal colonization enhanced the yield response, and a strong correlation $(r=0.83, P<0.05)$ was observed between AM colonization and the onion bulb growth (Figure 2).

Regarding the nutritional value of plants under different inoculation treatments, the values were either positively affected by the inoculation treatment or were not changed significantly. All inoculation treatments, but the singlefungus, (M1, S, S + M1, S + M2) enhanced significantly the total antioxidant capacity of bulb mass (Figure 3(b)). The highest values were found for the mix M1 $(27.5 \pm 3.98 \mathrm{mg}$ Trolox. $100 \mathrm{~g}^{-1}$ ) and both dual inoculations ( $+\mathrm{M} 1$ and S + M2 were $23.2 \pm 2.51$ and $19.3 \pm 3.48 \mathrm{mg}$ Trolox $\cdot 100 \mathrm{~g}^{-1}$, resp.). The G. intraradices inoculum itself did not enhance TAC but did cause a TAC increase when combined with saprotrophic fungi. The contents of nutritionally important elements in bulb tissue were enhanced in response to the microbial treatments with only some significant values. The Mg content (Figure 3(a)) was significantly increased in bulbs under the M2 treatment $\left(127.6 \pm 12.8 \mathrm{mg} \cdot \mathrm{kg}^{-1}\right)$ compared to the control plants $\left(\mathrm{Ctrl} 73.1 \pm 12.4 \mathrm{mg} \cdot \mathrm{kg}^{-1}\right)$. In the case of K content (Figure 3(b)), significantly increased values were found in treatment combinations involving of the AMF mix inoculum and in saprotrophic treatments (M2 $1411 \pm 84 \mathrm{mg} \cdot \mathrm{kg}^{-1}$, S $1769 \pm 22 \mathrm{mg} \cdot \mathrm{kg}^{-1}, \mathrm{~S}+\mathrm{M} 21879 \pm$ $25 \mathrm{mg} \cdot \mathrm{kg}^{-1}$ ), compared to the control plants (Ctrl $1411 \pm$ $\left.84 \mathrm{mg} \cdot \mathrm{kg}^{-1}\right)$. The contents of $\mathrm{Ca}$ and $\mathrm{Na}$ were not found to be affected significantly by the inoculation treatment and reached on average $46.5 \pm 13.5$ and $18.7 \pm 5.9 \mathrm{mg} \cdot \mathrm{kg}^{-1}$, respectively. Values of Ca content for individual treatments were Ctrl $35 \pm 19.0 \mathrm{mg} \cdot \mathrm{kg}^{-1}, \mathrm{M} 161 \pm 7.7 \mathrm{mg} \cdot \mathrm{kg}^{-1}, \mathrm{M} 235 \pm$ $14.5 \mathrm{mg} \cdot \mathrm{kg}^{-1}, \mathrm{~S} 55 \pm 4.8 \mathrm{mg} \cdot \mathrm{kg}^{-1}, \mathrm{~S}+\mathrm{M} 148 \pm 5.7 \mathrm{mg} \cdot \mathrm{kg}^{-1}$, $\mathrm{S}+\mathrm{M} 244 \pm 5.1 \mathrm{mg} \cdot \mathrm{kg}^{-1}$, and the values of $\mathrm{Na}$ content for individual treatments were Ctrl $19 \pm 2.5 \mathrm{mg} \cdot \mathrm{kg}^{-1}, \mathrm{M} 120 \pm$ $3.4 \mathrm{mg} \cdot \mathrm{kg}^{-1}, \mathrm{M} 216 \pm 8.1 \mathrm{mg} \cdot \mathrm{kg}^{-1}, \mathrm{~S} 22 \pm 4.8 \mathrm{mg} \cdot \mathrm{kg}^{-1}, \mathrm{~S}+$ M1 $20 \pm 3.8 \mathrm{mg} \cdot \mathrm{kg}^{-1}$, and S + M2 $15 \pm 10.6 \mathrm{mg} \cdot \mathrm{kg}^{-1}$. The content of vitamin $\mathrm{C}$ in onion was not found to be affected by the inoculation treatments, and its values ranged from 11 to $20 \mathrm{mg} \cdot \mathrm{kg}^{-1}$ with the average value of $15.1 \pm 4 \mathrm{mg} \cdot \mathrm{g}^{-1}$.

\section{Discussion}

Allium species and A. cepa in particular are regarded as highly AMF responsive plants [27]. Some of the reported increases are much higher than that observed in our study, which was only twice as high for the treatment with the M1 mix inoculum compared to control, uninoculated plants. For A. cepa, Hayman and Mosse [28] recorded an up to 18fold increase in the weight of mycorrhizal plants compared 


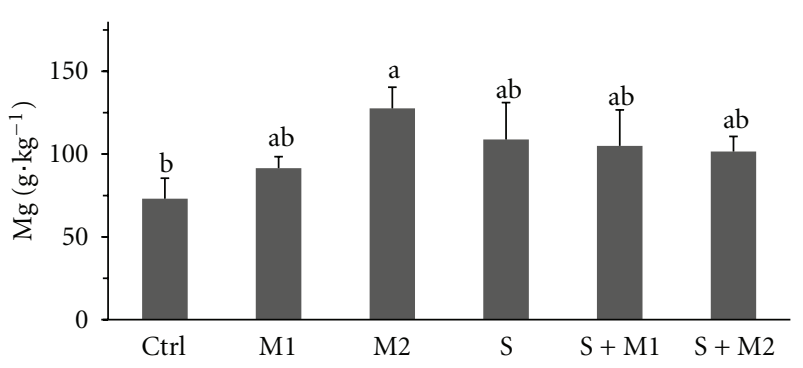

(a) Mg content

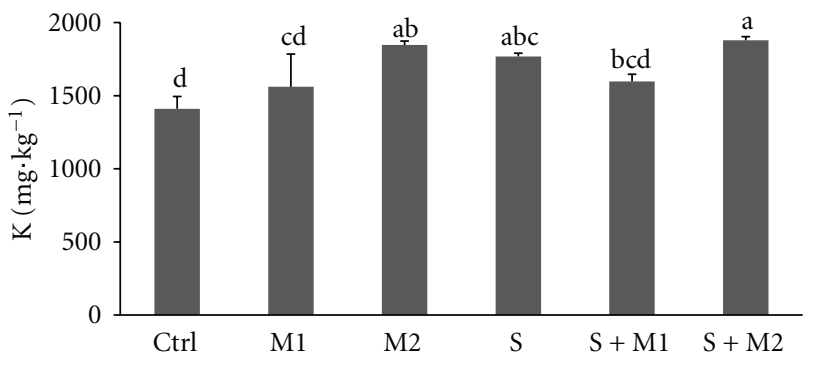

(b) K content

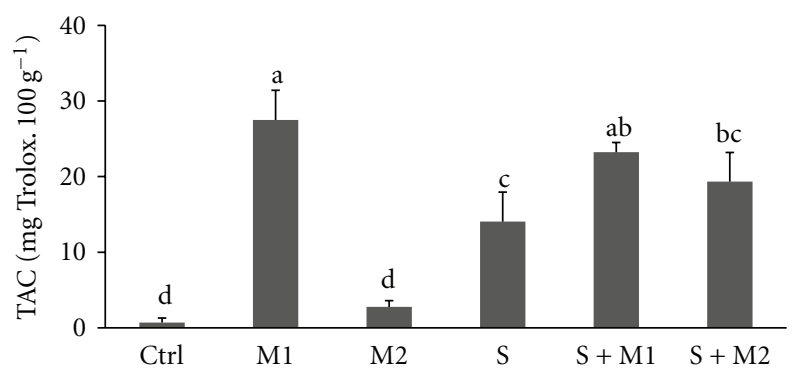

(c) Total antioxidant capacity

Figure 3: Contents of mineral elements $\mathrm{Mg}(\mathrm{a}), \mathrm{K}(\mathrm{b})$ and total antioxidant capacity determined by FRAP method (c) in onion bulb mass. Treatments: Ctrl—Control, M1—the mix of Glomus sp. (G. intraradices BEG140, G. mosseae BEG95, G. etunicatum BEG92, G. claroideum BEG96, G. microaggregatum BEG56, and G. geosporum BEG199), M2-G. intraradices BEG140, S—saprophytic fungi preinoculated bark chips (Gymnopilus sp. IZO24, Agrocybe praecox AER1, Marasmius androsaceus MAN1), S + M1, S + M2. Means \pm SD, columns marked with the same letters are not significantly different at the level $P<0.05$, Tukey HSD Test, $n=7$.

to nonmycorrhizal ones. Onion has a coarse root system without root hairs [29]. Such plants are often obligate mycorrhizal crops that are unable to complete their life cycle in the absence of AMF because of insufficient P uptake and hence insufficient growth [30, 31]. Mycorrhiza helps plants with such a shallow sparse root system to increase phosphorus uptake. AM fungi are, to different degree, capable of promoting phosphorus availability by acidifying the soil and, consequently, exploiting the phosphorus in nutrient patches and by facilitating the growth and development of host plants [32]. The observed high mycorrhizal responsiveness to mixed inoculum has been reported previously $[33,34]$, and it is thus often used in commercial products.

A similarly strong correlation $(r=0.70)$ between arbuscular colonization (\%) and onion yield (tons/ha) as in our case was found in an extensive survey of onion under conventional management conducted in the Netherlands [14], but the correlation was found to be much lower $(r=0.47)$ for onion grown in a field under organic management.

AMF directly or indirectly affects the soil ecosystem in different ways through multiple interactions with other soil organisms. Although they are not saprotrophs, AMF can enhance the rate of decomposition of organic material [35], indirectly influencing decomposition through interactions with other soil microorganisms [36]. Various interactions between AMF and saprotrophic fungi have been reported. Trichoderma in particular is now in the centre of attention because of its antagonistic effects against root pathogens and a possible synergistic interaction with AMF that helps promote plant growth. This synergy in the interaction appears to be very genotype-specific, however. Tiunov and Scheu [37] showed in their study that G. mosseae BEG12 suppressed the abundance of Trichoderma harzianum Rifai and Exophiala sp. while promoting the development and abundance of Ramichloridium schulzeri (Sacc.) de Hoog. Trichoderma genotypes exhibiting synergistic effects with AMF on growth of mycorrhizal plants have already been identified. Camprubi et al. [11] reported synergistic effects between $G$. intraradices and T. aureoviride on the growth of Citrus reshni in organic substrates. Tchameni et al. [12] observed positive effects of a mixture of two different mycorrhizal fungi (Gigaspora margarita and Acaulospora tuberculata) with the PR11 strain of Trichoderma asperellum promoting the growth of cacao trees. This mixture also induced resistance of cacao tree against the soil-borne pathogen Phytophthora megakarya.

The saprotrophic fungi used in the present study were selected because they are efficient saprotrophic decomposers of wood and litter. To our knowledge, this is the first time that such a combination of saprotrophic basidiomycete fungi, preinoculated on bark chips, has been used together with AMF inoculation to improve vegetable plants. It has been reported that A. praecox and other basidiomycetous decomposers in vitro under intermediate nitrogen supply promoted carbon mineralization and induced high levels of ligninase activity in $A$. praecox cultures grown on wood of black spruce (Picea mariana (Mill.) Britton, Sterns \& Poggenb.) [38]. This property of saprotrophic basidiomycetes, which helps plants retrieve nutrients from organic matter supplied in the form of woody material, thus may be utilized under conditions of low-input production schemes. 
The source of organic matter that is used as fertilizer in crop production may affect the achieved mycorrhizal responsiveness remarkably. Organic matter amendment in the form of ground leaves was found to lower the dry weight of shoots of AM cucumber plants compared to non-AM plants [39]. In the form of dried stems, it led to an increase in biomass of AM plants compared to non-AM plants of the tropical crop Desmodium ovalifolium L. [40]. Wheat bran amendment resulted in lowered biomass of non-AM tomato plants, but the biomass increased remarkably in plants treated either with a single inoculum containing AMF and the saprotrophic fungus Clonostachys rosea or a dual inoculation, which increased plant growth synergistically [41].

Plant genotype selection for reduced functioning of AM symbiosis under agricultural intensification was postulated a long time ago [42]. A recent genetic analysis of Allium species suggests that modern onion breeding does not select against the response to AMF [31], as has been suggested before for other cultivated species, for example, wheat [43]. In the present study, we therefore did not focus on genotypic specificity of host-plant microbe combinations. We instead focused on A. cepa cv. "ALICE", a genotype that is commonly used in high-input systems in the Czech Republic. Our results suggest promising applicability of the tested cultivation technology in commercial field production and small-scale cultivation alike.

During the last decades, improvements of nutritional quality brought about by microbial treatments, mycorrhiza in particular, have received increasing attention. Nell et al. [34], for example, reported positive effects of the same mixed inoculum as the one used in this study (M1) on the production of secondary metabolites (sesquiterpenic acids) by Valeriana sp. Recent studies also show that AM plants can contain higher amounts of nutritionally important elements. AMF inoculation, for example, significantly increased the total dry weight, leaf $\mathrm{P}, \mathrm{K}, \mathrm{Ca}, \mathrm{Mg}, \mathrm{Fe}, \mathrm{Cu}$, and $\mathrm{Mn}$ contents in trifoliate orange (Poncirus trifoliata L. Rafin.) seedlings [44], or $\mathrm{Cu}$ and $\mathrm{Fe}$ contents in lettuce [45]. Increases in $\mathrm{K}, \mathrm{Ca}, \mathrm{Mg}$, and Fe content were also found to be an effect of dual inoculation with AMF and saprobic fungi [46]. Researchers have recently recorded positive effects of AM on the content of different groups of compounds with antioxidative properties in harvested parts of crop plants, for example, organosulfur compounds in bunching onion [47], anthocyanins, carotenoids, and, to a lesser extent, phenolics in lettuce [45]. Arbuscular mycorrhizal fungi may support the production of organosulfur compounds under field conditions. In our study, we measured only the total antioxidant capacity, not specific compounds or chemical species, so we could not determine which species the observed increase should be ascribed to.

AMF inoculation might become very important for sustainable agronomical management, especially in cases when the efficiency of native inocula is poor [48]. Positive effects of AM inoculation with nonnative species on the growth and mycorrhizal colonization of onion plants were observed in five previous field experiments [49]. In last decades, the mycorrhizal industry has been developing an entire range of mycorrhizal products although the concern remains about inoculum quality [50]. An ongoing debate remains whether introduced AMF can survive in a form in which mycorrhizal symbionts are efficient in natural field conditions. Sequencing of fungal ITS has already provided several lines of evidence about the persistence of inoculated AMF after 2 years suggesting [20]. Another concern in application of AMF inoculants is about lowering AMF diversity in target ecosystems caused by outcompeting indigenous fungi by introduced nonnative fungal strains. Applications of tuned AM inocula derived from isolated native AMF strains from a particular ecosystem could overcome this problem and have been already the strategy of some commercial companies $[5,6]$.

\section{Conclusions}

Our results support the conclusion that there is a synergistic effect between dual microbial inoculation containing both AMF and saprotrophic fungi supplied together with organic matter. This ecological way of cultivation can lead to improvement of the parameters of onion plants as well as their nutritional value in sustainable production. Proper tuning of responsive genotypes of host plants, AMF, and saprotrophic fungi can bring not only a biomass increase but can also lead to improvement of nutritional quality. We believe that such synergistic dual fungal inoculations involving mycorrhizal and saprotrophic fungi together with organic matter supply have high potential for sustainable, environment-friendly production systems not only of onion but of crops in general.

\section{Abbreviations}

AMF: Arbuscular mycorrhizal fungi

AM: Arbuscular mycorrhiza

TAC: Total antioxidant capacity.

\section{Acknowledgments}

Support of the COST project Mykotech OC09057 in the framework of the COST Action 870 and Eurostars Project Microfruit E!4366 funded by the Ministry of Education, Youth and Sports of the Czech Republic is acknowledged. The technical help and contribution of Klara Prochazkova is acknowledged. The authors declare that they do not have a conflict of interests with any identities mentioned in the present paper. The company Symbiom Ltd. with its scientific division led by Dr. Ales Latr participated in the research study as the principal investigator of the Microfruit project and coinvestigator of the Mykotech project, which was led by Charles University in Prague.

\section{References}

[1] J. Roger-Estrade, C. Anger, M. Bertrand, and G. Richard, "Tillage and soil ecology: partners for sustainable agriculture," Soil and Tillage Research, vol. 111, no. 1, pp. 33-40, 2010.

[2] E. Lichtfouse, R. Habib, J. M. Meynard, and F. Papy, "Agronomy for sustainable development," Agronomie, vol. 24, no. 8, p. 445, 2004. 
[3] R. Lal, "Soils and sustainable agriculture. A review," Agronomy for Sustainable Development, vol. 28, no. 1, pp. 57-64, 2008.

[4] S. Gianinazzi, A. Gollotte, M. N. Binet, D. van Tuinen, D. Redecker, and D. Wipf, "Agroecology: the key role of arbuscular mycorrhizas in ecosystem services," Mycorrhiza, vol. 20, no. 8, pp. 519-530, 2010.

[5] S. Gianinazzi and M. Vosátka, "Inoculum of arbuscular mycorrhizal fungi for production systems: science meets business," Canadian Journal of Botany, vol. 82, no. 8, pp. 1264-1271, 2004.

[6] M. Vosatka and J. Albrechtova, "Theoretical aspects an practical uses of mycorrhizal technology in floriculture and horticulture," in Floriculture, Ornamental and Plant Biotechnology. Advances and Topical Issues, J. A. T. da Silva, Ed., vol. 5, pp. 466-479, Global Science Books Ltd, 2008.

[7] F. Y. Wang, R. J. Tong, Z. Y. Shi, X. F. Xu, and X. H. He, "Inoculations with Arbuscular mycorrhizal fungi increase vegetable yields and decrease phoxim concentrations in carrot and green onion and their soils," PLoS ONE, vol. 6, no. 2, e16949, 2011.

[8] F. Oehl, E. Sieverding, K. Ineichen, P. Mäder, T. Boller, and A. Wiemken, "Impact of land use intensity on the species diversity of arbuscular mycorrhizal fungi in agroecosystems of Central Europe," Applied and Environmental Microbiology, vol. 69, no. 5, pp. 2816-2824, 2003.

[9] F. Oehl, E. Sieverding, P. Mäder et al., "Impact of long-term conventional and organic farming on the diversity of arbuscular mycorrhizal fungi," Oecologia, vol. 138, no. 4, pp. 574-583, 2004.

[10] M. Gryndler, M. Vosátka, H. Hršelová, V. Catská, I. Chvátalová, and J. Jansa, "Effect of dual inoculation with arbuscular mycorrhizal fungi and bacteria on growth and mineral nutrition of strawberry," Journal of Plant Nutrition, vol. 25, no. 6, pp. 1341-1358, 2002.

[11] A. Camprubi, C. Calvet, and V. Estaun, "Growth enhancement of Citrus reshni after inoculation with Glomus intraradices and Trichoderma aureoviride and associated effects on microbial populations and enzyme activity in potting mixes," Plant and Soil, vol. 173, no. 2, pp. 233-238, 1995.

[12] S. N. Tchameni, M. E. L. Ngonkeu, B. A. D. Begoude et al., "Effect of Trichoderma asperellum and arbuscular mycorrhizal fungi on cacao growth and resistance against black pod disease," Crop Protection, vol. 30, no. 10, pp. 1321-1327, 2011.

[13] A. D. Bosch-Serra and L. Currah, "Agronomy of onions," in Allium Crop Science: Recent Advances, H. D. Rabinowitch and L. Currah, Eds., pp. 187-232, CAB International, Wallingford, UK, 2002.

[14] G. A. Galván, I. Parádi, K. Burger et al., "Molecular diversity of arbuscular mycorrhizal fungi in onion roots from organic and conventional farming systems in the Netherlands," $M y c$ orrhiza, vol. 19, no. 5, pp. 317-328, 2009.

[15] J. M. Phillips and D. S. Hayman, "Improved procedures for clearing roots and staining parasitic and vesicular-arbuscular mycorrhizal fungi for rapid assessment of infection," Transactions of the British Mycological Society, vol. 55, pp. 158-161, 1970.

[16] K. H. Miean and S. Mohamed, "Flavonoid (myricetin, quercetin, kaempferol, luteolin, and apigenin) content of edible tropical plants," Journal of Agricultural and Food Chemistry, vol. 49, no. 6, pp. 3106-3112, 2001.

[17] M. Corzo-Martínez, N. Corzo, and M. Villamiel, "Biological properties of onions and garlic," Trends in Food Science and Technology, vol. 18, no. 12, pp. 609-625, 2007.
[18] J. Park, J. Kim, and M. K. Kim, "Onion flesh and onion peel enhance antioxidant status in aged rats," Journal of Nutritional Science and Vitaminology, vol. 53, no. 1, pp. 21-29, 2007.

[19] M. A. Vazquez-Prieto and R. M. Miatello, "Organosulfur compounds and cardiovascular disease," Molecular Aspects of Medicine, vol. 31, no. 6, pp. 540-545, 2010.

[20] N. Ceccarelli, M. Curadi, L. Martelloni, C. Sbrana, P. Picciarelli, and M. Giovannetti, "Mycorrhizal colonization impacts on phenolic content and antioxidant properties of artichoke leaves and flower heads two years after field transplant," Plant and Soil, vol. 335, no. 1, pp. 311-323, 2010.

[21] R. Montalba, C. Arriagada, M. Alvear, and G. E. Zúñiga, "Effects of conventional and organic nitrogen fertilizers on soil microbial activity, mycorrhizal colonization, leaf antioxidant content, and Fusarium wilt in highbush blueberry (Vaccinium corymbosum L.)," Scientia Horticulturae, vol. 125, no. 4, pp. 775-778, 2010.

[22] I. F. F. Benzie and J. J. Strain, "The ferric reducing ability of plasma (FRAP) as a measure of 'antioxidant power': the FRAP assay," Analytical Biochemistry, vol. 239, no. 1, pp. 70-76, 1996.

[23] P. Blatny, F. Kvasnicka, R. Loucka, and H. Safarova, "Determination of ammonium, calcium, magnesium, and potassium in silage by capillary isotachophoresis," Journal of Agricultural and Food Chemistry, vol. 45, no. 9, pp. 3554-3558, 1997.

[24] S. P. Arya, M. Mahajan, and P. Jain, "Non-spectrophotometric methods for the determination of Vitamin C," Analytica Chimica Acta, vol. 417, no. 1, pp. 1-14, 2000.

[25] R. E. Koske and J. N. Gemma, "A modified procedure for staining roots to detect VA mycorrhizas," Mycological Research, vol. 92, pp. 486-505, 1989.

[26] M. Giovannetti and B. Mosse, "Evaluation of techniques for measuring vesicular-arbuscular mzcorrhiyal infection in roots," New Phytologist, vol. 84, no. 3, pp. 489-500, 1980.

[27] C. Plenchette, J. A. Fortin, and V. Furlan, "Growth responses of several plant species to mycorrhizae in a soil of moderate Pfertility-I. Mycorrhizal dependency under field conditions," Plant and Soil, vol. 70, no. 2, pp. 199-209, 1983.

[28] D. S. Hayman and B. Mosse, "Plant growth responses to vesicular-arbuscular mycorrhiza-I. Growth of endogoneinoculated plants in phosphate-deficient soils," New Phytologist, vol. 70, no. 1, pp. 19-27, 1971.

[29] C. A. M. Portas, "Development of root systems during the growth of some vegetable crops," Plant and Soil, vol. 39, no. 3, pp. 507-518, 1973.

[30] G. Charron, V. Furlan, M. Bernier-Cardou, and G. Doyon, "Response of onion plants to arbuscular mycorrhizae 1. Effects of inoculation method and phosphorus fertilization on biomass and bulb firmness," Mycorrhiza, vol. 11, no. 4, pp. 187-197, 2001.

[31] G. A. Galván, T. W. Kuyper, K. Burger et al., "Genetic analysis of the interaction between Allium species and arbuscular mycorrhizal fungi," Theoretical and Applied Genetics, vol. 122, no. 5, pp. 947-960, 2011.

[32] Z. Shi, F. Wang, C. Zhang, and Z. Yang, "Exploitation of phosphorus patches with different phosphorus enrichment by three arbuscular mycorrhizal fungi," Journal of Plant Nutrition, vol. 34, no. 8, pp. 1096-1106, 2011.

[33] C. Tu, F. L. Booker, D. M. Watson et al., "Mycorrhizal mediation of plant $\mathrm{N}$ acquisition and residue decomposition: impact of mineral N inputs," Global Change Biology, vol. 12, no. 5, pp. 793-803, 2006.

[34] M. Nell, C. Wawrosch, S. Steinkellner et al., "Root colonization by symbiotic arbuscular mycorrhizal fungi increases 
sesquiterpenic acid concentrations in Valeriana officinalis L," Planta Medica, vol. 76, no. 4, pp. 393-398, 2010.

[35] A. Hodge, C. D. Campbell, and A. H. Fitter, "An arbuscular mycorrhizal fungus accelerates decomposition and acquires nitrogen directly from organic material," Nature, vol. 413, no. 6853, pp. 297-299, 2001.

[36] J. Leigh, A. H. Fitter, and A. Hodge, "Growth and symbiotic effectiveness of an arbuscular mycorrhizal fungus in organic matter in competition with soil bacteria," FEMS Microbiology Ecology, vol. 76, no. 3, pp. 428-438, 2011.

[37] A. V. Tiunov and S. Scheu, "Arbuscular mycorrhiza and Collembola interact in affecting community composition of saprotrophic microfungi," Oecologia, vol. 142, no. 4, pp. 636642, 2005.

[38] S. D. Allison, D. S. LeBauer, M. R. Ofrecio, R. Reyes, A. M. Ta, and T. M. Tran, "Low levels of nitrogen addition stimulate decomposition by boreal forest fungi," Soil Biology and Biochemistry, vol. 41, no. 2, pp. 293-302, 2009.

[39] A. Albertsen, S. Ravnskov, H. Green, D. F. Jensen, and J. Larsen, "Interactions between the external mycelium of the mycorrhizal fungus Glomus intraradices and other soil microorganisms as affected by organic matter," Soil Biology and Biochemistry, vol. 38, no. 5, pp. 1008-1014, 2006.

[40] C. L. Boddington and J. C. Dodd, "The effect of agricultural practices on the development of indigenous arbuscular mycorrhizal fungi. II. Studies in experimental microcosms," Plant and Soil, vol. 218, no. 1-2, pp. 145-157, 2000.

[41] S. Ravnskov, B. Jensen, I. M. B. Knudsen et al., "Soil inoculation with the biocontrol agent Clonostachys rosea and the mycorrhizal fungus Glomus intraradices results in mutual inhibition, plant growth promotion and alteration of soil microbial communities," Soil Biology and Biochemistry, vol. 38, no. 12, pp. 3453-3462, 2006.

[42] N. C. Johnson, "Can fertilization of soil select less mutualistic mycorrhizae?” Ecological Applications, vol. 3, no. 4, pp. 749757, 1993.

[43] R. J. H. Sawers, C. Gutjahr, and U. Paszkowski, "Cereal mycorrhiza: an ancient symbiosis in modern agriculture," Trends in Plant Science, vol. 13, no. 2, pp. 93-97, 2008.

[44] Q. S. Wu and Y. N. Zou, "The effect of dual application of arbuscular mycorrhizal fungi and polyamines upon growth and nutrient uptake on trifoliate orange (Poncirus trifoliata) seedlings," Notulae Botanicae Horti Agrobotanici Cluj-Napoca, vol. 37, no. 2, pp. 95-98, 2009.

[45] M. Baslam, I. Garmendia, and N. Goicoechea, "Arbuscular mycorrhizal fungi (AMF) improved growth and nutritional quality of greenhouse-grown Lettuce," Journal of Agricultural and Food Chemistry, vol. 59, no. 10, pp. 5504-5515, 2011.

[46] C. Arriagada, I. Sampedro, I. Garcia-Romera, and J. Ocampo, "Improvement of growth of Eucalyptus globulus and soil biological parameters by amendment with sewage sludge and inoculation with arbuscular mycorrhizal and saprobe fungi," Science of the Total Environment, vol. 407, no. 17, pp. 47994806, 2009.

[47] H. Perner, S. Rohn, G. Driemel et al., "Effect of nitrogen species supply and mycorrhizal colonization on organosulfur and phenolic compounds in onions," Journal of Agricultural and Food Chemistry, vol. 56, no. 10, pp. 3538-3545, 2008.

[48] E. Pellegrino, S. Bedini, L. Avio, E. Bonari, and M. Giovannetti, "Field inoculation effectiveness of native and exotic arbuscular mycorrhizal fungi in a Mediterranean agricultural soil," Soil Biology and Biochemistry, vol. 43, no. 2, pp. 367-376, 2011.

[49] M. Vosatka, "Influence of inoculation with arbuscular mycorrhizal fungi on the growth and mycorrhizal infection of transplanted onion," Agriculture, Ecosystems and Environment, vol. 53, no. 2, pp. 151-159, 1995.

[50] M. Vosatka, J. Albrechtova, and R. Patten, "The international market development for mycorrhizal technology," in Mycorrhiza, A. Varma, Ed., chapter 21, pp. 438-419, Springer, 2008. 

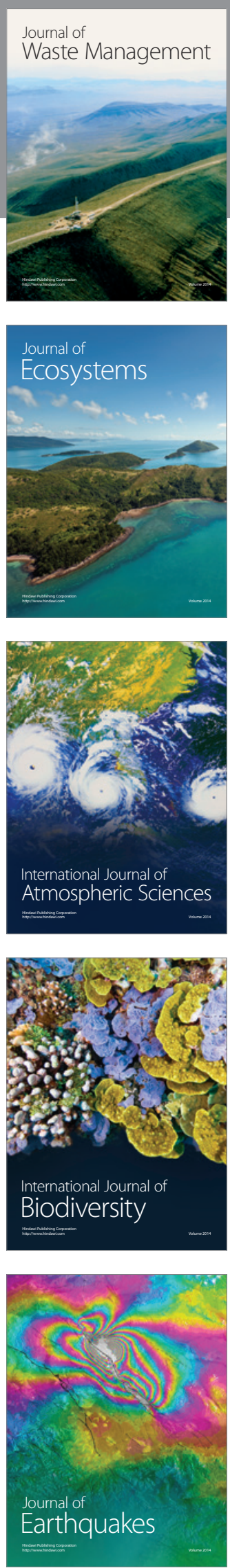
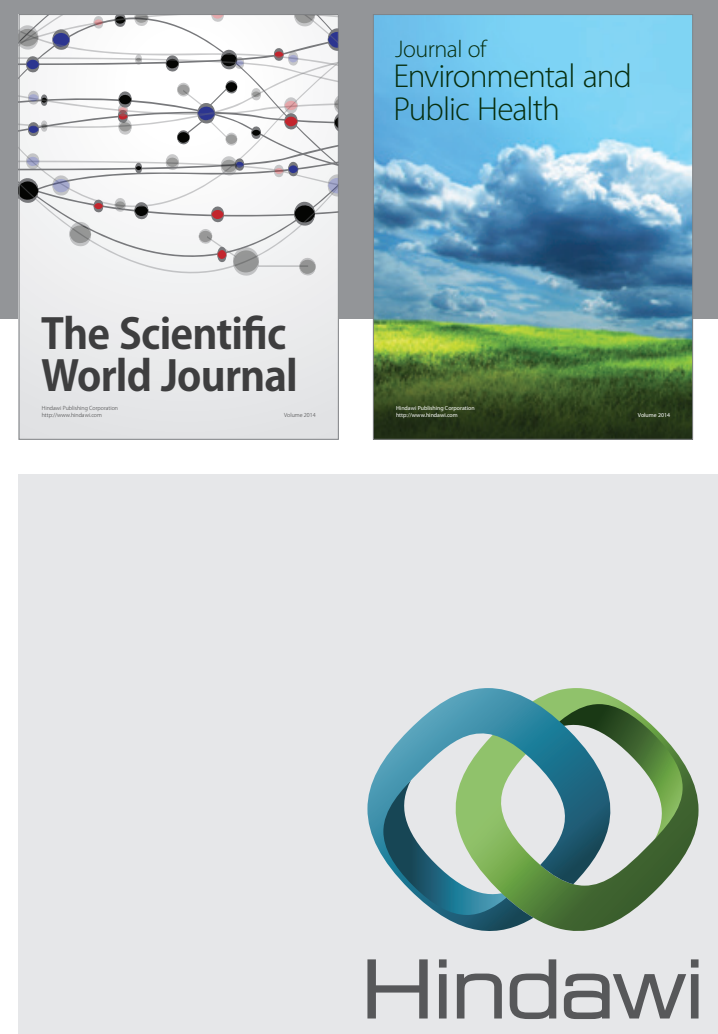

Submit your manuscripts at

http://www.hindawi.com
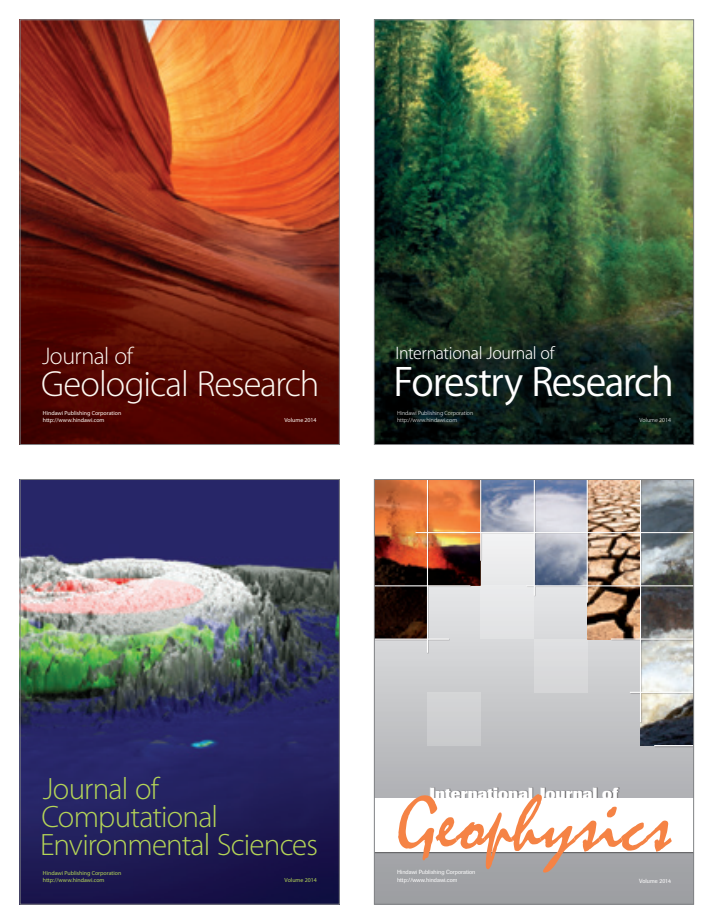
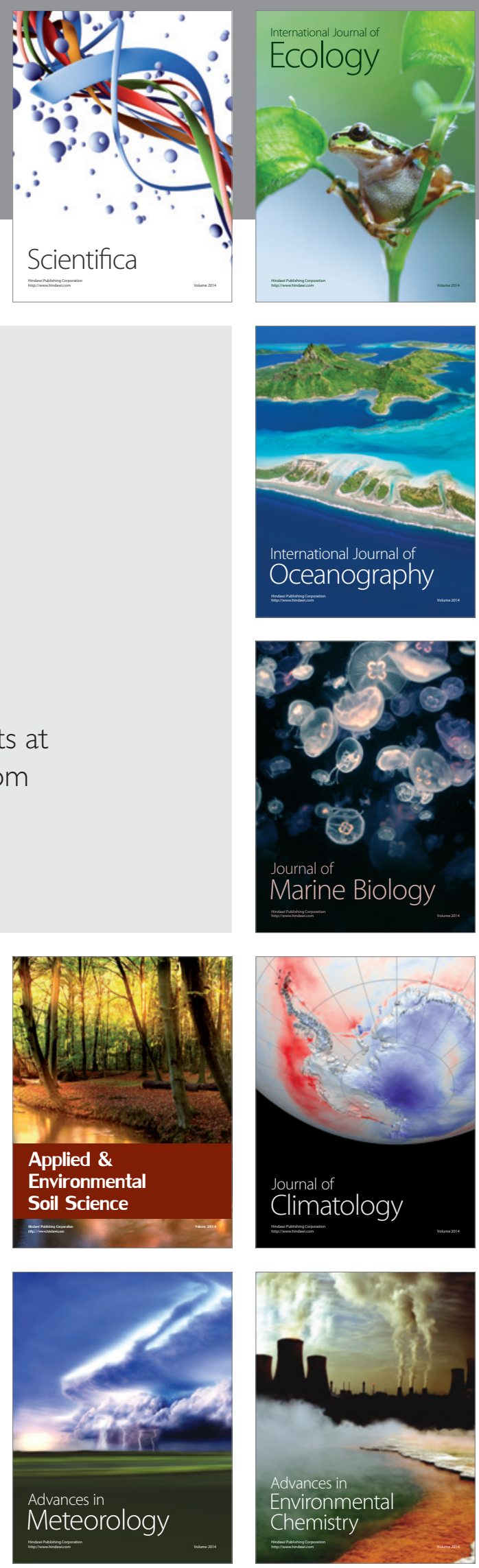